Check for updates

Zimbabwe

Cite this as: BMJ 2020;370:m3267 http://dx.doi.org/10.1136/bmj.m3267 Published: 19 August 2020

\section{Covid-19: Health worker strikes, limited testing, and clinic closures hamper Zimbabwe's response}

\author{
Ryan Truscott
}

Official figures on the impact of covid-19 in Zimbabwe belie a country grappling with health worker strikes, limited testing, and a closure of health facilities.

The country had had 141 deaths from covid-19 and 5378 recorded cases as of 20 August, nearly five months after the first fatality $\mathrm{bn} 23$ March. The people infected include 480 health workers, said the Ministry of Health.⿴囗十

At $14 \%$, the weekly percentage increase in infections in Zimbabwe from 5 to 11 August is also much lower than that of its neighbours. Botswana saw an increase of $33 \%$, Namibia $31 \%$, Zambia $26 \%$, and Mozambique $22 \%$ in the same week, figures from the World Health Organization showed. ${ }^{2}$

Chiratidzo Ndhlovu, an associate professor of medicine at the University of Zimbabwe, believes that the country's early imposition of lockdown may have helped avoid an initial surge in cases. "We didn't have a lot of flights coming into the country. I think that may have protected us," she said.

Serological testing capacity currently stands at 1000 to 1500 tests a day, up from just 25 tests on 10 April. But there are concerns in the medical community that testing is happening mostly in urban populations and that it may not capture current infection levels.

"There are several rapid response teams who do testing across the country, and those are the ones that get reported," said Rashida Ferrand, a professor at the London School of Hygiene and Tropical Medicine, UK, currently seconded to head up the covid-19 unit at Parirenyatwa Hospital in Harare. "But that doesn't tell you about the cases that are out in the community that don't get tested, or die and never make it to care. The cases reported in the national statistics are definitely a complete underestimate, as are the deaths.”

\section{Limited capacity}

Reinaldo Ortuno, Médecins Sans Frontières' head of mission in Harare, told The BMJ, "The number of tests outside Harare and Bulawayo is close to zero. [The authorities] are trying their best to improve the health system [and] to set up isolation facilities-they're doing the piping for oxygen, getting the supplies. But it's taking time."

Several health clinics outside main urban centres have had to close after infections were reported there. The most recently reported case was that of Chikonohono Clinic in Chinhoyi, northwest of Harare, on 15 August.

Staff strikes at hospitals that remain open also mean limited capacity to care for patients. Ferrand's 300 bed unit in Harare currently holds only 30 patients, partly because only limited numbers of patients are being referred.

The health workers' strike, which started in June over insufficient provision of personal protective equipment $(\mathrm{PPE})$ and low salaries has reduced capacity further (nurses earn the equivalent of US\$30 (€22.70; $€ 25.10)$ a month, doctors US\$115).

Aaron Musara, secretary general of the Zimbabwe Senior Hospital Doctors Association, believes that more clinical staff would have been infected if the nurses had not been on strike. "The government is not taking the issue of PPE seriously," he said.

Ortuno said that infections could rise, warning that "perhaps in October and November we will have a surge."

But hospitals may still not be ready to handle any increase in cases, said Ndhlovu, who also chairs the National Medicine and Therapeutics Policy Advisory Committee. "We have tried to make sure that we get the isolation and treatment centres ready to receive patients," she said, "but if we don't have the healthcare workers, at a minimum, to take care of these patients, we are going to struggle."

Moyo-Ndlovu T. More than 480 healthcare workers contract Covid-19. Chronicle2020 Aug 19. https://www.chronicle.co.zw/more-than-480-healthcareworkers-contract-covid-19/.

2 WHO Regional Office for Africa. Covid-19: situation update for the WHO Africa region. 12 Aug 2020. https://apps.who.int/iris/bitstream/handle/10665/333814/SITREP_COVID-19_WHOAFRO_20200812-eng.pdf.

This article is made freely available for use in accordance with BMJ's website terms and conditions for the duration of the covid-19 pandemic or until otherwise determined by BMJ. You may use, download and print the article for any lawful, non-commercial purpose (including text and data mining) provided that all copyright notices and trade marks are retained. 